\title{
UPAYA MENINGKATKAN PRESTASI BELAJAR PENDIDIKAN AGAMA ISLAM DENGAN MENERAPKAN MODEL PENGAJARAN KOLABORASI
}

\author{
Jalaludin \\ Sekolah Dasar Negeri 14 Pulau Kumbang \\ Email: Jalaludinsdn14@gmail.com
}

\begin{abstract}
This research is based on the problem (a) How is the improvement of PAI learning achievement by applying the collaborative teaching model for the fourth grade students of SDN 14 Pulau Kumbang in academic year 2017/2018 (b) What is the effect of the collaborative teaching model on the motivation of PAI learning for the fourth grade students of SDN 14 Pulau Kumbang 2017/2018. While the objectives of this research are (a) to find out the improvement of PAI learning achievement after the implementation of the collaborative teaching model (b) to know the effect of PAI learning motivation after applying the collaborative teaching model. This research uses action research as much as three cycles. Each round consists of four stages: planning, observing, reflecting and revising. The target of this research is the fourth grade students of SDN 14 Pulau Kumbang in academic year 2017/2018. The data obtained in the form of formative test results, observation sheets of teaching and learning activities. From the results of analysts, it was found that student achievement increased from cycle I to cycle III namely, cycle I (73.17\%), cycle II (82.93\%), cycle III $(95.12 \%)$. The conclusion of this study is the cooperative learning method can positively influence the achievement and motivation of students in class IV SDN 14 Pulau Kumbang in academic year 2017/2018 and this learning model can be used as an alternative to PAI learning.
\end{abstract}

\section{Keywords: PAI, Collaborative Teaching Model, Learning Outcomes}

\section{PENDAHULUAN}

Dalam kegiatan belajar mengajar yang berlangsung telah terjadi interaksi yang bertujuan. Guru dan anak didiklah yang menggerakannya. Interaksi yang bertujuan itu disebabkan gurulah yang memaknainya dengan menciptakan lingkungan yang bernilai edukatif demi kepentingan anak didik dalam belajar. Guru ingin memberikan layanan yang terbaik bagi anak didik, dengan menyediakan lingkungan yang menyenangkan dan menggairahkan. Guru berusaha menjadi pembimbing yang baik dengan peranan yang arif dan bijaksana, sehingga tercipta hubungan dua arah yang harmonis antara guru dengan anak didik.

Ketika kegiatan belajar itu berproses, guru harus dengan ikhlas dalam bersikap dan berbuat, serta mau memahami anak didiknya dengan segala konsekuensinya. Semua kendala yang terjadi dan dapat menjadi penghambat jalannya proses belajar mengajar, baik yang berpangkal dari perilaku anak didik maupun yang bersumber dari luar anak didik, harus guru hilangkan, dan bukan membiarkannya. Karena keberhasilan belajar mengajar lebih banyak ditentukan oleh guru dalam mengelola kelas.

Dalam mengajar, guru harus pandai menggunakan pendekatan secara arif dan bijaksana, bukan sembarangan yang bisa merugikan anak didik. Pandangan guru terhadap anak didik akan menentukan sikap dan perbuatan. Setiap guru tidak selalu mempunyai pandangan yang sama dalam menilai anak didik. Hal ini akan mempengaruhi pendekatan yang guru ambil dalam pengajaran.

Guru yang memandang anak didik sebagai pribadi yang berbeda dengan anak 
didik lainnya akan berbeda dengan guru yang memandang anak didik sebagai makhluk yang sama dan tidak ada perbedaan dalam segala hal. Maka adalah penting meluruskan pandangan yang keliru dalam menilai anak didik. Sebaiknya guru memandang anak didik sebagai individu dengan segala perbedaannya, sehingga mudah melakukan pendekatan dalam pengajaran.

Kualitas pembelajaran ditentukan oleh interaksi komponen-komponen dalam sistemnya. Yaitu tujuan, bahan ajar (materi), anak didik, sarana, media, metode, partisipasi masyarakat, performance sekolah, dan evaluasi pembelajaran (Moh, Shochib, 1998). Performance sekolah, dan evaluasi pembelajaran (Moh, Shochib, 1998). Optimalisasi komponen ini, menentukan kualitas (proses dan produk) pembelajaran. Upaya yang dapat dilakukan oleh pendidik adalah melakukan analisis tentang karakteristik setiap komponen dan mensinkronisasikan sehingga ditemukan konsistensi dan keserasian di antaranya untuk tercapainya tujuan pembelajaran. Karena pembelajaran mulai dari perencana, pelaksanaan dan evaluasinya senantiasa merujuk pada tujuan yang diharapkan untuk dikuasai atau dimiliki oleh anak didik baik instructional effect (sesuai dengan tujuan yang dirancang) maupun nurturrant effect (dampak pengiring) (Moch. Shochib: 1999).

Realisasi pencapaian tujuan tersebut, terdapat kegiatan interaksi belajar mengajar terutama yang terjadi di kelas. Dengan demikian, kegiatannya adalah bagaimana terjadi hubungan antara guru/bahan ajar yang didesain dan dengan anak didik. Interaksi ini merupakan proses komunikasi penyampaian pesan pembelajaran. Hal ini sejalan dengan yang dikemukakan Arief S Sadiman yang menyatakan proses belajar mengajar pada hakekatnya adalah proses interaksi yaitu proses penyampaian pesan melalui saluran media/teknik/ metode ke penerima pesan. (Arief S, Sadiman, dkk, 1996:13).

Sejalan dengan inovasi pembelajaran akhir-akhir ini termasuk di Sekolah Dasar, yaitu: Kolaborasi. Interaksi belajar mengajarnya menuntut anak didik untuk aktif, kreatif dan senang yang melibatkan secara optimal mental dan fisik mereka. Tingkat keaktifan, kreatifitas, dan kesenangan mereka dalam belajar merupakan rentangan kontinum dari yang paling rendah sampai yang paling tinggi. Tetapi idealnya pada kontinum yang tertinggi baik pelibatan aspek mental maupun fisik anak didik. Oleh karena itu, interaksi belajar mengajar dengan paradigma Kolaborasi menuntut anak: (1) Berbuat, (2) Terlibat dalam kegiatan, (3) Mengamati secara visual, (4) Mencerap informasi secara verbal

Dengan demikian, interaksi belajar mengajar idealnya mampu membelajarkan anak didik berdasarkan problem based learning, authentic instruction, inquiry based learning, project based learning, service learning, and cooperative learning. Pola interaksi yang mampu mengemas hal tersebut dapat mengubah paradigma pembelajaran aktif menjadi paradigma pembelajaran reflektif.

Dengan interaksi pembelajaran reflektif dapat membuat anak didik untuk menjadikan hasil belajar sebagai referensi refleksi kritis tentang dampak ilmu pengetahuan dan teknologi terhadap masyarakat; mengasah kepedulian sosial, mengasah hati nurani, dan bertanggungjawab terhadap karirnya kelak. Kemampuan ini dimiliki anak didik, karena dengan pola interaksi pembelajaran tersebut, dapat membuat anak didik aktif dalam berfikir (mind-on), aktif dalam berbuat (hand-on), mengembangkan kemampuan bertanya, mengembangkan kemampuan berkomunikasi, dan membudayakan untuk memecahkan permasalahan baik secara personal maupun sosial.

Agar hasil ini dapat optimal, guru dituntut untuk mengubah peran dan fungsinya menjadi fasilitator, mediator, mitra belajar anak didik, dan evaluator. Ini berarti, guru harus menciptakan interaksi pembelajaran yang demokratis dan dialogis antara guru dengan anak didik, dan anak didik dengan anak didik (Moh. Shochib: 1999; dan Paul Suparno dkk: 2001).

Dengan interaksi pembelajaran yang mengemas nilai-nilai tersebut dapat membuat 
pembelajaran lingking (link and math atau life skill) dan delinking (pemutusan lingkungan negatif), diversifikasi kurikulum, pembelajaran kontekstual, kurikulum berbasis kompetensi, dan otonomi pendidikan pada tingkat sekolah taman kanak-kanak dengan manajemen berbasis sekolah, dan bertujuan untuk mengupayakan fondasi dan mengembangkan anak untuk memiliki kemampuan yang utuh yang disebut: Pendidikan Anak Seutuhnya (PAS).

Pada dasarnya dalam kehidupan suatu bangsa, faktor pendidikan mempunyai peranan yang sangat penting untuk menjamin perkembangan dan kelangsungan hidup bangsa tersebut. Secara langsung maupun tidak langsung pendidikan adalah suatu usaha sadar dalam menyiapkan pertumbuhan dan perkembangan anak melalui kegiatan, bimbingan, pengajaran dan pelatihan bagi kehidupan dimasa yang akan datang. Tentunya hal ini merupakan tanggung jawab bersama antara pemerintah, anggota masyarakat dan orang tua. Untuk mencapai keberhasilan ini perlu dukungan dan partisipasi aktif yang bersifat terus menerus dari semua pihak.

Guru mengemban tugas yang berat untuk tercapainya tujuan pendidikan nasional yaitu meningkatkan kualitas manusia Indonesia, manusia seutuhnya yang beriman dan bertakwa terhadap Tuhan Yang Maha Esa, berbudi pekerti luhur, berkepribadian, berdisiplin, bekerja keras, tangguh, bertanggung jawab, mandiri, cerdas dan terampil serta sehat jasmani dan rohani, juga harus mampu menumbuhkan dan memperdalam rasa cinta terhadap tanah air, mempertebal semangat kebangsaan dan rasa kesetiakawanan sosial. Sejalan dengan itu pendidikan nasional akan mampu mewujudkan manusia-manusia pembangunan dan membangun dirinya sendiri serta bertanggung jawab atas pembangunan bangsa. Depdikbud (1999).

Berhasilnya tujuan pembelajaran ditentukan oleh banyak faktor diantaranya adalah faktor guru dalam melaksanakan proses belajar mengajar, karena guru secara langsung dapat mempengaruhi, membina dan meningkatkan kecerdasan serta keterampilan siswa. Untuk mengatasi permasalahan di atas dan guna mencapai tujuan pendidikan secara maksimal, peran guru sangat penting dan diharapkan guru mampu menyampaikan semua mata pelajaran yang tercantum dalam proses pembelajaran secara tepat dan sesuai dengan konsep-konsep mata pelajaran yang akan disampaikan.

Sesuai dengan permasalahan di atas, penelitian ini bertujuan untuk: (1) Mengetahui peningkatan prestasi belajar Pendidikan Agama Islam setelah diterapkannya model pengajaran kolaborasi pada siswa kelas IV SDN 14 Pulau Kumbang tahun pelajaran 2017/2018. (2) Mengetahui pengaruh motivasi belajar Pendidikan Agama Islam setelah diterapkan model pengajaran kolaborasi pada siswa kelas IV SDN 14 Pulau Kumbang tahun pelajaran 2017/2018. (3) Menyempurnakan pelaksanaan pembelajaran Pendidikan Agama Islam dalam meningkatkan prestasi belajar pada siswa kelas IV SDN 14 Pulau Kumbang tahun pelajaran 2017/2018.

Adapun maksud penulis mengadakan penelitian ini diharapkan dapat berguna sebagai: (1) Menambah pengetahuan dan wawasan penulis tentang peranan guru Pendidikan Agama Islam dalam meningkatkan pemahaman siswa belajar Pendidikan Agama Islam. (2) Sumbangan pemikiran bagi guru Pendidikan Agama Islam dalam mengajar dan meningkatkan pemahaman siswa belajar Pendidikan Agama Islam. (3) Sebagai bahan pertimbangan dalam menentukan metode pembelajaran yang dapat memberikan manfaat bagi siswa. (4) Sebagai penentu kebijakan dalam upaya meningkatkan prestasi belajar siswa khususnya pada mata pelajaran Pendidikan Agama Islam. Menerapkan metode yang tepat sesuai dengan materi pelajaran Pendidikan Agama Islam.

Pembelajaran adalah proses, cara, menjadikan orang atau makhluk hidup belajar. Sedangkan belajar adalah berusaha memperoleh kepandaian atau ilmu berubah tingkah laku atau tanggapan yang disebabkan oleh pengalaman, (KBBI, 1996:14) 
Sependapat dengan pernyataan tersebut Sutomo (1993:68) mengemukakan bawah belajar adalah proses pengelolaan lingkungan seseorang dengan sengaja dikelukan sehingga memungkinkan dia belajar untuk melakukan atau mempertunjukkan tingkah laku pula. Sedangkan belajar adalah suatu proses yang menyebabkan perubahan tingkah laku yang bukan disebabkan oleh proses pertumbuhan yang bersifat fisik, tetapi perubahan dalam kebiasaan, kecakapan, bertambah pengetahuan, berkembang daya pikir, sikap dan lain-lain (Soetomo, 1993:120)

adalah proses yang disengaja yang menyebabkan siswa belajar pada suatu lingkungan belajar untuk melakukan kegiatan pada situasi tertentu.

Salah satu cara utama untuk mendapatkan rasa aman adalah menjalin hubungan dengan orang lain dan menjadi bagian dari kelompok. Perasaan saling memiliki ini memungkinkan siswa untuk menghadapi tantangan. Ketika mereka belajar bersama teman, bukannya sendirian, mereka mendapatkan dukungan emosional dan intelektual yang memungkinkan mereka mendapatkan dukungan emosional dan intelektual yang memungkinkan mereka melampaui ambang pengetahuan dan keterampilan mereka yang sekarang.

Jerome Bruinner membahas sisi social proses belajar dalam buku klasiknya Toward a Theory of Instruction. Dia menjelaskan tentang " kebutuhan mendalam manusia untuk merespon orang lain dan untuk bekerjasama dengan mereka guna mencapai tujuan," yang mana hal ini dia sebut resiprositas (hubungan timbal balik). Bruner berpendapat bahwa resiprositas merupakan sumber motivasi yang bisa dimanfaatkan oleh guru sebagai berikut, "Di mana dibutuhkan tindakan bersama dan dimana resiprositas diperlukan bagi kelompok untuk mencapai suatu tujuan, disitulah terdapat proses yang membawa individu ke dalam pembelajaran membimbingnya untuk mendapatkan kemampuan yang diperlukan dalam pembentukan kelompok" (Bruner, 1966)

Konsep-konsepnya Maslow dan Bruner mengurusi perkembangan metode belajar kolaborasi yang sedemikian popular dalam lingkup pendidikan masa kini. Menempatkan siswa dalam kelompok dan memberi mereka tugas yang menuntut untuk bergantung satu sama lain dalam mengerjakannya merupakan cara yang bagus untuk memanfaatkan kebutuhan social siswa. Mereka menjadi cenderung lebih terlibat dalam kegiatan belajar karena mereka mengerjakannya bersama teman-teman. Begitu terlibat, mereka juga langsung memiliki kebeutuhan untuk membicarakan apa yang mereka alami bersama teman yang mengarah kepada hubungan-hubungan lebih lanjut.

Kegiatan belajar bersama dapat mambantu memacu belajar aktif. Kegiatan belajar dan mengajar di kelas memang dapat menstimulasi belajar aktif dengan cara khusus. Apa yang didiskusikan siswa dengan teman-temannya dan apa yang diajarkan siswa kepada teman-temannya memungkinkan mereka untuk memperoleh pemahaman dan penguasaan materi pelajaran. Metode belajar bersama yang terbaik, semisal pelajaran menyusun gambar (jigsaw), memenuhi persyaratan ini . pemberian tugas yang berbeda kepada siswa akan mendorong mereka untuk tidak hanya belajar bersama namun juga mengajarkan satu sama lain.

Pengajaran tradisional menitik beratkan pada mtode imposisi, yakni pengajaran dengan cara menuangkan hal-hal yang dianggap penting oleh guru bagi murid (Hamalik, Oemar: 2001:157). Cara ini tidak mempertimbangkan apakah bahan pelajaran yang diberikan itu sesuai atau tidak dengan kesanggupan, kebutuhan, minat dan tingkat kesanggupan, serta pemahaman murid. Tidak pula diperhatikan apakah bahan-bahan yang diberikan itu didasarkan atas motif-motif dan tujuan yang ada pada murid.

Sejak adanya penemuan-penemuan baru dalam bidang psikologi tentang kepribadian dan tingkah laku manusia serta perkembangan dalam bidang ilmu pendidikan makan pandangan tersebut kemudian berubah. Faktor siswa didik justru menjadi unsure yang menentukan berhasil atau tidaknya pengajaran berdasaran " pusat 
minat" anak makan, pakaian, permaian/bekerja. Kemudian menyusul tokoh pendidikan lainnya sepert Dr John Dewey, yang terkenal dengan " pengajaran proyeknya" yang berdasarkan pada masalah yang menarik minat siswa, system perkolahan lainnya. Sehingga sejak itu pula para ahli berpendapat, bahwa tingkah laku manusia didorong oleh motif-motif tertentu dan perbuatan belajar akan berhasil apabila didasarkan pada motivasi yan ada pada murid. Murid dapat dipaksa untuk mengikuti semua perbuatan, tetapi Ia tidak dapat dipaksa untuk menghayati perbuatan itu sebagaimana mestinya. Seekor kuda dapat digiring ke sungai tetapi tidak dapat dipaksa untuk minum. Demikian pula juga halnya dengan murid, guru dapat memaksanya untuk belajar dalam arti sesungguhnya. Inilah yang menjadi tugas yang paling berat yakni bagaimana caranyua berusaha agar murid mau belajar dan memiliki keinginan untuk belajar secara kontinyu.

Motif adalah daya dalam diri seseorang yang mendorongnya untuk melakukan sesuatu atau keadaan seseorang atau organisme yang menyebabkan kesiapannya untuk memulai serangkaian tingkah laku atau perbuatan. Sedangkan motivasi adalah sesuatu proses untuk menggiatkan motifmotif menjadi perbuatan atau tingkah laku untuk memenuhi kebutuhan dan mencapai tujuan atau keadaan dan kesiapan dalam diri individu yang mendorong tingkah lakunya untuk berbuat sesuatu dalam mencapai tujuan tertentu (Usman 2000:28).

Sedangkan menurut Djamarah (2002:114) motivasi adalah suatu pendorong yang mengubah energi dalam diri seseorang kedalam bentuk aktivitas nyata untuk mencapai tujuan tertentu . dalam proses belajar, motivasi sangat diperlukan sebab seseorang yang tidak mempunyai motivasi dalam belajar tidak akan mungkin melakukan aktivitas belajar. Hal ini sesuai dengan yang diungkapkan oleh Nur (2001:3) bahwa siswa yang termotivasi dalam belajar sesuatu akan menggunakan proses kognitif yang lebih tinggi dalam mempelajari materi itu, sehingga siswa itu akan menyerap dan mengendapkan materi itu dengan lebih baik.

Jadi motivasi aalah suatu kondisi yang mendorong seseorang untujk berbuat sesuatu dalam mencapai tujuan tertentu. Jenis motivasi ini timbul sebagai akibat dari dalam individu apakah karena adanya ajakan, suruhan, atau paksaan dari orang lain sehingga dengan kondisi yang demikian akhirnya ia mau melakukan sesuatu atau belajar (Usman, 2000:29).

Beberapa cara membangkitkan motivasi ekstrinsik dalam menumbuhkan motivasi instrinsik antara lain: (1) Kompetisi (persaingan) guru berusaha menciptakan persaingan diantra siswanya untuk meningkatkan prestasi belajarnya, berusaha memperbaiki hasil prestasi yang telah dicapai sebelumnya dan mengatasi prestasi orang lain. (2) Pace Making (Membuat tujuan sementara atau dekat). Pada awal kegiatan belajar mengajar, guru hendaknya terlebih dahulu menyampaikan kepada siswa TIK yang akan dicapai sehingga dengan demikian siswa berusaha untuk mencapai TIK tersebut. (3) Tujuan yang jelas : motif mendorong individu untuk mencapai tujuan. Makin jelas tujuan makin besar nilai tujuan bagi individu yang bersangkutan dan makin besar pula motivasi dalam melakukan sesuatu perbuatan. (4) Kesempurnaan untuk sukses: kesuksesan dapat menimbulkan rasa puas, kesenangan dan kepercayaan terhadap diri sendiri, sedangkan kegagalan akan membawa efek yang sebaliknya. Dengan demikian guru hendaknya banyak memberikan kesempatan kepada anak untuk meraih sukses dengan usaha mandiri tentu saja dengan bimbingan guru. (5) Minat yang besar : motif akan timbul jika individu memiliki minat yang besar. (6) Mengadakan penilaian atau tes. Pada umumnya semua siswa mau belajar dengan tujuan memperoleh nilai yang baik. Hal ini terbukti dalam kenyataan bawha banyak siswa yang tidak belajar bila tidak ada ulangan. Akan tetapi bila guru mengatakan bahwa lusa akan diadakan ulangan lisan, barulah siswa giat belajar dengan menghafal agar ia mendapat nilai 
yang baik, jadi angka atau nilai itu merupakan motivasi yang kuat bagi siswa.

Dari uraian di atas diketahui bahwa motivasi ekstrinsik adalah motivasi yang timbul dari luar individu yang fungsinya karena adanya perangsang dari luar, misalnya adanya persaingan, untuk mencapai nilai yang tinggi, dan lain sebagainya.

Telah disepakati oleh pendidikan bahwa guru merupakan kunci dalam proses belajar mengajar. Bila hal ini dilihat dari segi nilai lebih yang dimiliki oleh guru dibandingkan dengan siswanya.nilai lebih ini dimiliki oleh guru terutama dalam ilmu pengetahuan yang dimiliki oleh guru bidang studi pengajarannya. Walau demikian nilai lebih itu tidak akan dapat diandalkan oleh guru, apabila ia tidak memiliki teknik-teknik yang tepat untuk mentransfer kepada siswa. Disamping itu kegiatan mengajar adalah suatu aktivitas yang sangat kompleks , karena itu sukar bagi guru PAI bagaimana caranya mengajar dengan baik agar dapat meningkatkan motivasi siswa dalam belajar PAI.

Pembelajaran kolaborasi (Colaboration Learning) merupakan model pembelajaran yang menerapkan paradigma baru dalam teori-teori belajar (Yufiarti 2003). Pendekatan ini dapat digambarkan sebagai suatu moel pembelajaran dengan menumbuhkan para siswa untuk bekerja sama dalam kelompok-kelompok kecil untu mencapai tujuan yang sama.

Pendekatan kolaborasi bertujuan agar siswa dapat membangun pengetahuannya melalui dialog, saling membagi informasi sesame siswa dan guru sehingga siswa dapat meningkatkan kemampuan mental pada tingkat tinggi. Model ini digunakan pada setiap mata pelajaran terutama yang mungkin berkembang sharing of information di antara siswa

Peran guru dalam model pembelajaran kolaboratif adalah sebagai mediator. Guru menghubungkan informasi baru terhadap pengalaman siswa dengan proses belajar di bidang lain, membantu siswa menentukan apa yang harus dilakukan jika siswa mengalami kesulitan dan membantu mereka belajar tentang bagaimana caranya belajar. Lebih dari itu, guru sebagai mediator menyesuaikan tingkat informasi siswa dan mendorong agar siswa memaksimalkan kemampuannya untuk bertanggung jawab atas proses belajar mengajar selanjutnya.

Sebagai mediator guru menjalani tiga peran, yaitu berfungsi sebagai fasilitator, model dan pelatih. Sebagai fasilitator guru menciptakan lingkungan dan kreativitas yang kaya guna membantu siswa membangun pengetahuannya. Dalam rangka menjalankan peran ini, ada tiga hal pula yang harus dikerjakan. Pertama, mengatur lingkungan fisik, termasuk pengaturan tata letak perabot dalam ruangan serta persediaan berbagai sumber daya dan peralatan yang dapat membantu proses belajar mengajar siswa. Kedua, menyediakan lingkungan social yang mendukung proses belajar siswa, seperti mengelompokkan siswa secara heterogen dan mengajak siswa mengembangkan struktur social yang mendorong munculnya perilaku yang sesuai untuk berkolaborasi antar siswa, ketiga, guru memberikan tugas memancing munculnya interaksi antarsiswa dengan lingkungan fisik maupun social di sekitarnya. Dalam hal ini, guru harus mampu memotivasi anak.

Peran sebagai model dapat diwujudkan dengan cara membagi pikiran tentang suatu hal (thinking aloud) atau menunjukkan pada siswa tentang bagaimana melakukan sesuatu secara bertahap (demonstrasi) . Di samping itu menunjukkan pada siswa bagaimana cara berpikir sewaktu melalui situasi kelompok yang sulit dan melalui masalah komunikasi adalah sama pentingnya dengan mencontohkan bagaimana cara membuat perencanaan, memonitor penyelesaian tugas dan mengukur apa yang sudah dipelajari.

Peran guru sebagai pelatih mempunyai prinsip utama yaitu menyediakan bantuan secukupnya pada saat siswa membutuhkan sehingga siswa tetap memagang tanggung jawab atas proses belajar mereka sendiri. Hal ini dilakukan dengan memberikan petunjuk dam umpan balik, mengarahkan kembali usaha siswa serta membantu mereka menggunakan strategi tertentu. 
Salah satu ciri penting dari kelas yang menerapkan model pembelajaran kolaboratif adalah siswa tidak dikotak-kotakan berdasarkan kemampuannya, minatnya, ataupun karakteristik dan mengurangi kesempatan siswa untu belajar bersama siswa lain. Dengan demikian, semua siswa dapat belajar dari siswa dan tidak ada siswa yang tidak mempunyai kesempatan untuk memberikan masukan dan menghargai masukan yang diberikan orang lain.

Model kolaboratif dapat digambarkan sebagai berikut. Ketika terjadi kolaboratif, semua siswa aktif. Mereka saling berkomunikasi secara alami. Dalam sebuah kelompok yang terdiri atas 4 sampai 6 anak, di sana guru sudah membuat rancangan agar siswa yang satu dengan yang lain bisa berkolaborasi. Dalam kelompok yang sudah ditentukan oleh guru, fasilitas yang ada pun diusahakan anak mampu berkolaborasi. Misalnya dalam kelompok yang terdiri atas 4 sampai 6 tersebut seorang guru hanya menyiapkan 2 sampai 3 kotak alat mewarna yang dipakai secara bergantian. Dengan harapan setiap siswa bisa berkomunikasi satu dengan yang lain. Dengan komunikasi aktif antar siswa akan terjalin hubungan yang baik dan saling menghargai. Alat tersebut bukan milik pribadi, melainkan sudah menjadi milik bersama. Setiap anak tidak merasa memiliki secara pribadi, tetapi bisa dipakai bersama. Paa saat yang sama mempunyai keinginan untuk memakainya maka aka terjadi komunikasi yagn alami dengan penggunaan santun bahasa. Dalam kondisi seperti ini seperti guru hanya mengamati cara kerja siswa dan cara berkomunikasi serta menjadi pembanding saat siswa memerlukan bantuan.

Untuk kolaborasi dalam sebuah mata pelajaran, seorang guru memberikan tugas secara kelompok dengan tujuan yang sama. Setiap siswa dalam kelompok saling berkolaborasi dengan membagi pengalaman. Dari pengalaman yang dimiliki oleh masingmasing kelompok, disimpulkan secara bersama. Dalam hal in guru berperan sebagai pembimbing dan membagi tugas supaya diskusi kelompok bisa berjalan dengan baik dengan yang direncanakan.
Dalam kelas yang menggunakan model pembelajaran kolaboratif, situasi yang terjadi adalah pengetahuan yang terbagi antara guru dan siswa. Dengan kata lailn, baik guru maupun siswa dipandang sebagai sumber informas. Situasi ini jelas berbeda dengan situasi yang umumnya terjadi dalam kelas tradisional. Dalam kelas tradisional guru dipandang sebagai satu-satunya sumber informasi dan pengetahuan yang mengalir satu arah dari guru ke murid atau semua pembelajaran berpusat pada guru.

Untuk mencapai tujuan yang efektif, seorang guru perlu menciptakan berbagai cara mengajar yang sesuai dengan mata pelajaran sehingga dapat berjalan efektif.

\section{METODE PENELITIAN}

Penelitian ini merupakan penelitian tindakan (action research), karena penelitian dilakukan untuk memecahkan masalah pembelajaran di kelas. Penelitian ini juga termasuk penelitian deskriptif, sebab menggambarkan bagaimana suatu teknik pembelajaran diterapkan dan bagaimana hasil yang diinginkan dapat dicapai.

Menurut Sukidin dkk (2002:54) ada 4 macam bentuk penelitian tindakan, yaitu: (1) penelitian tindakan guru sebagai peneliti, (2) penelitian tindakan kolaboratif, (3) penelitian tindakan simultan terintegratif, dan penelitian tindakan sosial eksperimental.

Keempat bentuk penelitian tindakan di atas, ada persamaan dan perbedaannya. Menurut Oja dan Smulyan sebagaimana dikutip oleh Kasbolah, (2000) (dalam Sukidin, dkk. 2002:55), ciri-ciri dari setiap penelitian tergantung pada: (1) tujuan utamanya atau pada tekanannya, (2) tingkat kolaborasi antara pelaku peneliti dan peneliti dari luar, (3) proses yang digunakan dalam melakukan penelitian, dan (4) hubungan antara proyek dengan sekolah.

Dalam penelitian ini menggunakan bentuk guru sebagai peneliti, dimana guru sangat berperan sekali dalam proses penelitian tindakan kelas. Dalam bentuk ini, tujuan utama penelitian tindakan kelas ialah untuk meningkatkan praktik-praktik pembelajaran di kelas. Dalam kegiatan ini, 
guru terlibat langsung secara penuh dalam proses perencanaan, tindakan, observasi, dan refleksi. Kehadiran pihak lain dalam penelitian ini peranannya tidak dominan dan sangat kecil.

Penelitian ini mengacu pada perbaikan pembelajaran yang berkesinambungan. Kemmis dan Taggart (1988:14) menyatakan bahwa model penelitian tindakan adalah berbentuk spiral. Tahapan penelitian tindakan pada suatu siklus meliputi perencanaan atau pelaksanaan observasi dan refleksi. Siklus ini berlanjut dan akan dihentikan jika sesuai dengan kebutuhan dan dirasa sudah cukup.

Tempat penelitian adalah tempat yang digunakan dalam melakukan penelitian untuk memperoleh data yang diinginkan. Penelitian ini bertempat kelas IV SDN 14 Pulau Kumbang tahun pelajaran 2017/2018.

Waktu penelitian adalah waktu berlangsungnya penelitian atau saat penelitian ini dilangsungkan. Penelitian ini dilaksanakan pada bulan Agustus sampai November 2017.

Subyek penelitian adalah siswa-siswi kelas IV SDN 14 Pulau Kumbang tahun pelajaran 2017/2018.

Menurut pengertiannya penelitian tindakan adalah penelitian tentang hal-hal yang terjadi di masyarakat atau sekelompok sasaran, dan hasilnya langsung dapat dikenakan pada masyarakat yang bersangkutan (Arikunto, Suharsimi 2002:82). Ciri atau karakteristik utama dalam penelitian tindakan adalah adanya partisipasi dan kolaborasi antara peneliti dengan anggota kelompok sasaran. Penelitian tindakan adalah satu strategi pemecahan masalah yang memanfaatkan tindakan nyata dalam bentuk proses pengembangan inovatif yang dicoba sambil jalan dalam mendeteksi dan memecahkan masalah. Dalam prosesnya pihak-pihak yang terlibat dalam kegiatan tersebut dapat saling mendukung satu sama lain.

Sedangkan tujuan penelitian tindakan harus memenuhi beberapa prinsip sebagai berikut: (1) Permasalahan atau topik yang dipilih harus memenuhi kriteria, yaitu benarbenar nyata dan penting, menarik perhatian dan mampu ditangani serta dalam jangkauan kewenangan peneliti untuk melakukan perubahan. (2) Kegiatan penelitian, baik intervensi maupun pengamatan yang dilakukan tidak boleh sampai mengganggu atau menghambat kegiatan utama. (3) Jenis intervensi yang dicobakan harus efektif dan efisien, artinya terpilih dengan tepat sasaran dan tidak memboroskan waktu, dana dan tenaga. (4) Metodologi yang digunakan harus jelas, rinci, dan terbuka, setiap langkah dari tindakan dirumuskan dengan tegas sehingga orang yang berminat terhadap penelitian dapat mengecek setiap hipotesis dan pembuktiannya. (5) Kegiatan penelitian diharapkan dapat merupakan proses kegiatan yang berkelanjutan (on-going), mengingat bahwa pengembangan dan perbaikan terhadap kualitas tindakan memang tidak dapat berhenti tetapi menjadi tantangan sepanjang waktu. (Arikunto, Suharsimi, 2002:82-83).

Sesuai dengan jenis penelitian yang dipilih, yaitu penelitian tindakan, maka penelitian ini menggunakan model penelitian tindakan dari Kemmis dan Taggart (dalam Arikunto, Suharsimi, 2002:83), yaitu berbentuk spiral dari siklus yang satu ke siklus yang berikutnya. Setiap siklus meliputi planning (rencana), action (tindakan), observation (pengamatan), dan reflection (refleksi). Langkah pada siklus berikutnya adalah perencanaan yang sudah direvisi, tindakan, pengamatan, dan refleksi.

Alat pengumpul data dalam penelitian ini adalah tes buatan guru yang fungsinya adalah: (1) untuk menentukan seberapa baik siswa telah menguasai bahan pelajaran yang diberikan dalam waktu tertentu, (2) untuk menentukan apakah suatu tujuan telah tercapai, dan (3) untuk memperoleh suatu nilai (Arikunto, Suharsimi, 2002:149). Sedangkan tujuan dari tes adalah untuk mengetahui ketuntasan belajar siswa secara individual maupun secara klasikal. Di samping itu untuk mengetahui letak kesalahan-kesalahan yang dilakukan siswa sehingga dapat dilihat dimana kelemahannya, khususnya pada bagian mana TPK yang belum tercapai. Untuk memperkuat data yang 
dikumpulkan maka juga digunakan metode observasi (pengamatan) yang dilakukan oleh teman sejawat untuk mengetahui dan merekam aktivitas guru dan siswa dalam proses belajar mengajar.

Dalam rangka menyusun dan mengolah data yang terkumpul sehingga dapat menghasilkan suatu kesimpulan yang dapat dipertanggungjawabkan, maka digunakan analisis data kuantitatif dan pada metode observasi digunakan data kualitatif. Cara penghitungan untuk mengetahui ketuntasan belajar siswa dalam proses belajar mengajar sebagai berikut : (1) Merekapitulasi hasil tes, (2) Menghitung jumlah skor yang tercapai dan prosentasenya untuk masing-masing siswa dengan menggunakan rumus ketuntasan belajar seperti yang terdapat dalam buku petunjuk teknis penilaian yaitu siswa dikatakan tuntas secara individual jika mendapatkan nilai minimal 65 , sedangkan secara klasikal dikatakan tuntas belajar jika jumlah siswa yang tuntas secara individu mencapai $85 \%$ yang telah mencapai daya serap lebih dari sama dengan 65\%. (3) Menganalisa hasil observasi yang dilakukan oleh guru sendiri selama kegiatan belajar mengajar berlangsung.

\section{HASIL DAN PEMBAHASAN PENELITIAN \\ Hasil}

\section{Siklus I}

Suatu pokok bahasan atau sub pokok bahasan dianggap tuntas secara klasikal jika siswa yang mendapat nilai 65 lebih dari atau sama dengan $85 \%$, sedangkan seorang siswa dinyatakan tuntas belajar pada pokok bahasan atau sub pokok bahasan tertentu jika mendapat nilai minimal 65 .

Pada tahap ini peneliti mempersiapkan perangkat pembelajaran yang terdiri dari rencana pelajaran 1 , soal tes formatif 1 dan alat-alat pengajaran yang mendukung. Selain itu juga dipersiapkan lembar observasi pengelolaan model pembelajaran Kolaborasi , dan lembar observasi aktivitas guru dan siswa.

Pelaksanaan kegiatan belajar mengajar untuk siklus I dilaksanakan pada tanggal 4 September 2017 di Kelas VI jumlah siswa 22 siswa. Dalam hal ini peneliti bertindak sebagai pengajar. Adapun proses belajar mengajar mengacu pada rencana pelajaran yang telah dipersiapkan. Pengamatan (observasi) dilaksanakan bersamaan dengan pelaksanaan belajar mengajar.

Pada akhir proses belajar mengajar siswa diberi tes formatif I dengan tujuan untuk mengetahui tingkat keberhasilan siswa dalam proses belajar mengajar yang telah dilakukan. Adapun data hasil penelitian pada siklus I adalah sebagai berikut.

Tabel 1. Rekapitulasi Hasil Tes Formatif Siswa Pada Siklus I

\begin{tabular}{clc}
\hline No & \multicolumn{1}{c}{ Uraian } & Hasil Siklus I \\
\hline 1 & Nilai rata-rata tes formatif & 70,00 \\
2 & Jumlah siswa yang tuntas belajar & 15 \\
3 & Persentase ketuntasan belajar & 68,18 \\
\hline
\end{tabular}

Dari tabel di atas dapat dijelaskan bahwa dengan menerapkan pembelajaran model Kolaborasi diperoleh nilai rata-rata prestasi belajar siswa adalah 70,00 dan ketuntasan belajar mencapai $68,18 \%$ atau ada 15 siswa dari 22 siswa sudah tuntas belajar. Hasil tersebut menunjukkan bahwa pada siklus pertama secara klasikal siswa belum tuntas belajar, karena siswa yang memperoleh nilai $\geq 65$ hanya sebesar $68,18 \%$ lebih kecil dari persentase ketuntasan yang dikehendaki yaitu sebesar $85 \%$. Hal ini disebabkan karena siswa masih merasa baru dan belum mengerti apa yang dimaksudkan dan digunakan guru dengan menerapkan pembelajaran model Kolaborasi.

Dalam pelaksanaan kegiatan belajar mengajar diperoleh informasi dari hasil 
pengamatan sebagai berikut: (1) Guru kurang maksimal dalam memotivasi siswa dan dalam menyampaikan tujuan pembelajaran. Guru kurang maksimal dalam pengelolaan waktu. (3) Siswa kurang aktif selama pembelajaran berlangsung.

Pelaksanaan kegiatan belajar mengajar pada siklus I ini masih terdapat kekurangan, sehingga perlu adanya revisi untuk dilakukan pada siklus berikutnya. (1) Guru perlu lebih terampil dalam memotivasi siswa dan lebih jelas dalam menyampaikan tujuan pembelajaran. Dimana siswa diajak untuk terlibat langsung dalam setiap kegiatan yang akan dilakukan. (2) Guru perlu mendistribusikan waktu secara baik dengan menambahkan informasi-informasi yang dirasa perlu dan memberi catatan. (3) Guru harus lebih terampil dan bersemangat dalam memotivasi siswa sehingga siswa bisa lebih antusias.

\section{Siklus II}

Pelaksanaan kegiatan belajar mengajar untuk siklus II dilaksanakan pada tanggal 11 Oktober 2017 di Kelas VI dengan jumlah siswa 22 siswa. Dalam hal ini peneliti bertindak sebagai pengajar. Adapun proses belajar mengajar mengacu pada rencana pelajaran dengan memperhatikan revisi pada siklus I, sehingga kesalahan atau kekurangan pada siklus I tidak terulang lagi pada siklus II. Pengamatan (observasi) dilaksanakan bersamaan dengan pelaksanaan belajar mengajar.

Pada akhir proses belajar mengajar siswa diberi tes formatif II dengan tujuan untuk mengetahui tingkat keberhasilan siswa dalam proses belajar mengajar yang telah dilakukan. Instrumen yang digunakan adalah tes formatif II. Adapun data hasil penelitian pada siklus II adalah sebagai berikut.

Tabel 2. Rekapitulasi Hasil Tes Formatif Siswa Pada Siklus II

\begin{tabular}{clc}
\hline No & \multicolumn{1}{c}{ Uraian } & Hasil Siklus II \\
\hline 1 & Nilai rata-rata tes formatif & 77,73 \\
2 & Jumlah siswa yang tuntas belajar & 17 \\
3 & Persentase ketuntasan belajar & 79,01 \\
\hline
\end{tabular}

Dari tabel di atas diperoleh nilai ratarata prestasi belajar siswa adalah 77,73 dan ketuntasan belajar mencapai $79,01 \%$ atau ada 17 siswa dari 22 siswa sudah tuntas belajar. Hasil ini menunjukkan bahwa pada siklus II ini ketuntasan belajar secara klasikal telah mengalami peningkatan sedikit lebih baik dari siklus I. Adanya peningkatan hasil belajar siswa ini karena setelah guru menginformasikan bahwa setiap akhir pelajaran akan selalu diadakan tes sehingga pada pertemuan berikutnya siswa lebih termotivasi untuk belajar. Selain itu siswa juga sudah mulai mengerti apa yang dimaksudkan dan diinginkan guru dengan menerapkan pembelajaran model Kolaborasi.

Dalam pelaksanaan kegiatan belajar diperoleh informasi dari hasil pengamatan sebagai berikut: (1) Memotivasi siswa. (2) Membimbing siswa merumuskan kesimpulan/menemukan konsep.

Pengelolaan waktu.

Pelaksanaan kegiatan belajar pada siklus II ini masih terdapat kekurangan-kekurangan. Maka perlu adanya revisi untuk dilaksanakan pada siklus II antara lain: (1) Guru dalam memotivasi siswa hendaknya dapat membuat siswa lebih termotivasi selama proses belajar mengajar berlangsung. (2) Guru harus lebih dekat dengan siswa sehingga tidak ada perasaan takut dalam diri siswa baik untuk mengemukakan pendapat atau bertanya. (3) Guru harus lebih sabar dalam membimbing siswa merumuskan kesimpulan/menemukan konsep. (4) Guru harus mendistribusikan waktu secara baik sehingga kegiatan pembelajaran dapat berjalan sesuai dengan yang diharapkan. (5) Guru sebaiknya menambah lebih banyak contoh soal dan memberi soal-soal latihan pada siswa untuk 
dikerjakan pada setiap kegiatan belajar mengajar.

\section{Siklus III}

Pada tahap ini peneliti mempersiapkan perangkat pembelajaran yang terdiri dari rencana pelajaran 3 , soal tes formatif 3 dan alat-alat pengajaran yang mendukung.

Pelaksanaan kegiatan belajar mengajar untuk siklus III dilaksanakan pada tanggal 4 November 2017 di kelas IV SDN 14 Pulau Kumbang tahun pelajaran 2017/2018 dengan jumlah siswa 22 siswa. Dalam hal ini peneliti bertindak sebagai pengajar. Adapun proses belajar mengajar mengacu pada rencana pelajaran dengan memperhatikan revisi pada siklus II, sehingga kesalahan atau kekurangan pada siklus II tidak terulang lagi pada siklus III. Pengamatan (observasi) dilaksanakan bersamaan dengan pelaksanaan belajar mengajar.

Pada akhir proses belajar mengajar siswa diberi tes formatif III dengan tujuan untuk mengetahui tingkat keberhasilan siswa dalam proses belajar mengajar yang telah dilakukan. Instrumen yang digunakan adalah tes formatif III. Adapun data hasil penelitian pada siklus III adalah sebagai berikut.

Tabel 3. Hasil Formatif Siswa Pada Siklus III

\begin{tabular}{clc}
\hline No & \multicolumn{1}{c}{ Uraian } & Hasil Siklus III \\
\hline 1 & Nilai rata-rata tes formatif & 82,73 \\
2 & Jumlah siswa yang tuntas belajar & 19 \\
3 & Persentase ketuntasan belajar & 86,36 \\
\hline
\end{tabular}

Berdasarkan tabel di atas diperoleh nilai rata-rata tes formatif sebesar 82,73 dan dari 22 siswa telah tuntas sebanyak 19 siswa dan 3 siswa belum mencapai ketuntasan belajar. Maka secara klasikal ketuntasan belajar yang telah tercapai sebesar $86,36 \%$ (termasuk kategori tuntas). Hasil pada siklus III ini mengalami peningkatan lebih baik dari siklus II. Adanya peningkatan hasil belajar pada siklus III ini dipengaruhi oleh adanya peningkatan kemampuan guru dalam menerapkan pembelajaran model Kolaborasi sehingga siswa menjadi lebih terbiasa dengan pembelajaran seperti ini sehingga siswa lebih mudah dalam memahami materi yang telah diberikan.

Pada tahap ini akan dikaji apa yang telah terlaksana dengan baik maupun yang masih kurang baik dalam proses belajar mengajar dengan penerapan pembelajaran model Kolaborasi. Dari data-data yang telah diperoleh dapat diuraikan sebagai berikut: (1) Selama proses belajar mengajar guru telah melaksanakan semua pembelajaran dengan baik. Meskipun ada beberapa aspek yang belum sempurna, tetapi persentase pelaksanaannya untuk masing-masing aspek cukup besar. (2) Berdasarkan data hasil pengamatan diketahui bahwa siswa aktif selama proses belajar berlangsung. (3) Kekurangan pada siklus-siklus sebelumnya sudah mengalami perbaikan dan peningkatan sehingga menjadi lebih baik. (4) Hasil belajar siswa pada siklus III mencapai ketuntasan.

Pada siklus III guru telah menerapkan pembelajaran model Kolaborasi dengan baik dan dilihat dari aktivitas siswa serta hasil belajar siswa pelaksanaan proses belajar mengajar sudah berjalan dengan baik. Maka tidak diperlukan revisi terlalu banyak, tetapi yang perlu diperhatikan untuk tindakan selanjutnya adalah memaksimalkan dan mempertahankan apa yang telah ada dengan tujuan agar pada pelaksanaan proses belajar mengajar selanjutnya penerapan model pengajaran kolaborasi dapat meningkatkan proses belajar mengajar sehingga tujuan pembelajaran dapat tercapai.

\section{Pembahasan}

Melalui hasil penelitian ini menunjukkan bahwa pembelajaran model Kolaborasi memiliki dampak positif dalam meningkatkan prestasi belajar siswa. Hal ini dapat dilihat dari semakin mantapnya pemahaman siswa terhadap materi yang 
disampaikan guru (ketuntasan belajar meningkat dari siklus I, II, dan III) yaitu masing-masing $\quad 68,18 \%, \quad 79,01 \%$, dan $86,36 \%$. Pada siklus III ketuntasan belajar siswa secara klasikal telah tercapai.

Berdasarkan analisis data, diperoleh aktivitas siswa dalam proses belajar mengajar dengan menerapkan model pengajaran kolaborasi dalam setiap siklus mengalami peningkatan. Hal ini berdampak positif terhadap prestasi belajar siswa yaitu dapat ditunjukkan dengan meningkatnya nilai ratarata siswa pad setiap siklus yang terus mengalami peningkatan.

Berdasarkan analisis data, diperoleh aktivitas siswa dalam proses pembelajaran PAI pada pokok bahasan kisah nabi Ibrahim a.s, dan nabi Ismail a.s dengan model pengajaran kolaborasi yang paling dominan adalah, mendengarkan/memperhatikan penjelasan guru, dan diskusi antar siswa/antara siswa dengan guru. Jadi dapat dikatakan bahwa aktivitas siswa dapat dikategorikan aktif.

Sedangkan untuk aktivitas guru selama pembelajaran telah melaksanakan langkahlangkah kegiatan belajar mengajar dengan menerapkan pengajaran konstekstual model pengajaran berbasis masalah dengan baik. Hal ini terlihat dari aktivitas guru yang muncul di antaranya aktivitas membimbing dan mengamati siswa dalam menemukan konsep, menjelaskan materi yang sulit, memberi umpan balik/evaluasi/tanya jawab dimana prosentase untuk aktivitas di atas cukup besar.

\section{SIMPULAN DAN SARAN Simpulan}

Berdasarkan hasil penelitian yang telah dipaparkan selama tiga siklus, hasil seluruh pembahasan serta analisis yang telah dilakukan dapat disimpulkan sebagai berikut: (1) Model pengajaran kolaborasi dapat meningkatkan kualitas pembelajaran PAI. (2) Pembelajaran model Kolaborasi memiliki dampak positif dalam meningkatkan prestasi belajar siswa yang ditandai dengan peningkatan ketuntasan belajar siswa dalam setiap siklus, yaitu siklus I $(68,18 \%)$, siklus II
$(79,01 \%)$, siklus III $(86,36 \%)$. (2) Model pengajaran kolaborasi dapat menjadikan siswa merasa dirinya mendapat perhatian dan kesempatan untuk menyampaikan pendapat, gagasan, ide dan pertanyaan. (3) Siswa dapat bekerja secara mandiri maupun kelompok, serta mampu mempertanggungjawabkan segala tugas individu maupun kelompok. (4) Penerapan pembelajaran model Kolaborasi mempunyai pengaruh positif, yaitu dapat meningkatkan motivasi belajar siswa.

\section{Saran}

Dari hasil penelitian yang diperoleh dari uraian sebelumnya agar proses belajar mengajar PAI lebih efektif dan lebih memberikan hasil yang optimal bagi siswa, maka disampaikan saran sebagai berikut: (1) Untuk melaksanakan model pengajaran kolaborasi memerlukan persiapan yang cukup matang, sehingga guru harus mampu menentukan atau memilih topik yang benarbenar bisa diterapkan dengan pembelajaran model Kolaborasi dalam proses belajar mengajar sehingga diperoleh hasil yang optimal. (2) Dalam rangka meningkatkan prestasi belajar siswa, guru hendaknya lebih sering melatih siswa dengan berbagai metode pengajaran, walau dalam taraf yang sederhana, dimana siswa nantinya dapat menemukan pengetahuan baru, memperoleh konsep dan keterampilan, sehingga siswa berhasil atau mampu memecahkan masalahmasalah yang dihadapinya.

Untuk penelitian yang serupa hendaknya dilakukan perbaikan-perbaikan agar diperoleh hasil yang lebih baik.

\section{DAFTAR PUSTAKA}

Ali, Muhammad. 1996. Guru Dalam Proses Belajar Mengajar. Bandung: Sinar Baru Algesindon.

Arikunto, Suharsimi. 1993. Manajemen Mengajar Secara Manusiawi. Jakarta: Rineksa Cipta.

Arikunto, Suharsimi. 2001. Dasar-dasar Evaluasi Pendidikan. Jakarta: Bumi Aksara. 
Arikunto, Suharsimi. 2002. Prosedur Penelitian Suatu Pendekatan Praktek. Jakarta: Rineksa Cipta.

Azhar, Lalu Muhammad. 1993. Proses Belajar Mengajar Pendidikan. Jakarta: Usaha Nasional.

Daroeso, Bambang. 1989. Dasar dan Konsep Pendidikan Moral Pancasila. Semarang: Aneka Ilmu.

Djamarah, Syaiful Bahri. 2002. Strategi Belajar Mengajar. Jakarta: Rineksa Cipta.

Djamarah, Syaiful Bahri. 2002. Psikologi Belajar. Jakarta: Rineksa Cipta.

Hadi, Sutrisno. 1982. Metodologi Research, Jilid 1. Yogyakarta: YP. Fak. Psikologi UGM.

Hamalik, Oemar. 2002. Psikologi Belajar dan Mengajar. Bandung: Sinar Baru Algesindo.

Hasibuan K.K. dan Moerdjiono. 1998. Proses Belajar Mengajar. Bandung: Remaja Rosdakarya.

Margono. 1997. Metodologi Penelitian Pendidikan. Jakarta. Rineksa Cipta.

Masriyah. 1999. Analisis Butir Tes. Surabaya: Universitas Press.
Ngalim, Purwanto M. 1990. Psikologi Pendidikan. Bandung: PT. Remaja Rosdakarya.

Nur, Moh. 2001. Pemotivasian Siswa untuk Belajar. Surabaya: University Press. Univesitas Negeri Surabaya.

Rustiyah, N.K. 1991. Strategi Belajar Mengajar. Jakarta: Bina Aksara.

Sardiman, A.M. 1996. Interaksi dan Motivasi Belajar Mengajar. Jakarta: Bina Aksara.

Soekamto, Toeti. 1997. Teori Belajar dan Model Pembelajaran. Jakarta: PAUPPAI, Universitas Terbuka.

Sukidin, dkk. 2002. Manajemen Penelitian Tindakan Kelas. Surabaya: Insan Cendekia.

Surakhmad, Winarno. 1990. Metode Pengajaran Nasional. Bandung: Jemmars.

Suryosubroto, B. 1997. Proses Belajar Mengajar di Sekolah. Jakarta: PT. Rineksa Cipta.

Syah, Muhibbin. 1995. Psikologi Pendidikan, Suatu Pendekatan Baru. Bandung: Remaja Rosdakarya.

Usman, Moh. Uzer. 2001. Menjadi Guru Profesional. Bandung: Remaja Rosdakarya. 